\title{
Pots, trade and the archaic Greek economy
}

\author{
ROBIN OSBORNE*
}

Fine painted pottery is the archaeological trade-mark of the Greek presence overseas. Since other materials of exchange in the Classical world - soft things like grain, oil and slaves - are less archaeologically visible, a fresh look at issues in the archaic Greek economy revolves once more around patterns in the ceramics.

Central to Moses Finley's characterization of the ancient economy was his claim that Greek and Roman society "was not organized for the satisfaction of its material wants by "an enormous conglomeration of interdependent markets"' (1985: 22). A lot is at stake in the claim that markets were not interdependent. In the world of independent markets, exchange is marginal to a fundamentally subsistence economy: local supply and demand fixes prices. In the world of the interdependent market, global demand for a particular commodity has an effect not simply on the price of that commodity but upon other commodity prices also: production and marketing decisions are affected by events far away from the place of production. In this world not all goods are produced for a market, nor is there a free market for all goods, but goods are regularly exchanged and those engaged in exchange are aware of varying demand for particular commodities in different places. Crucially the structure of exchange is not determined by the highly variably demand for staple foodstuffs.

In this paper I argue that the archaic Greek world was a world of interdependent markets. In concentrating on the archaeological evidence I inevitably concentrate on pottery, and I attempt to reveal the significance of the non-random distribution of archaic Athenian pots for the character and structure of the archaic Greek economy ( $c f$. Webster 1972: chapter 20; Boardman 1979: 37-9; Hannestad 1989: 112-14; Robinson 1990). I am not concerned with the value of pottery, with why people bought Athe- nian pottery rather than local or Corinthian pottery, with the social origins and political impact of those engaged in trade (on which $c f$. Cartledge 1983 on Mele 1979 and Bravo 1977; also Ste Croix 1981), or with the importance of the Phoenicians as carriers of early Greek pottery into the western Mediterranean (Shefton 1982), although my claims for the volume and economic significance of trade in non-agricultural goods have implications for these issues also. The evidence I deal with is unusually subject to vagaries of excavation, identification, and publication, but the features currently apparent seem to me to justify the attempt at interpretation.

\section{Sizing up the market}

The clearest indication that the mechanisms of exchange enabled goods to be precisely targeted comes from the distribution of the products of the 'Nikosthenic' workshop at Athens, which operated during the second half of the 6 th century BC. Some $96 \%$ of this workshop's pots of known archaeological provenance (findspot) come from the Etruscan area, and it produced pots whose shapes copied the shapes of Etruscan bucchero pottery. What is more, different shapes catered for different Etruscan markets: most of the around 100 Nikosthenic amphorae known have been found at Cerveteri (FIGURE 1), most of the around 400 Nikosthenic small kyathoi from Vulci and Orvieto (Rasmussen 1985: 38). But the most recent discussion of these pots (Arafat \& Morgan 1994: 115-16) follows a long line of ancient histori-

\footnotetext{
* Corpus Christi College, Oxford ox1 4JF, England.
}

Received 21 April 1995, accepted 12 September 1995.

ANTIQUITY 70 (1996): 31-44 


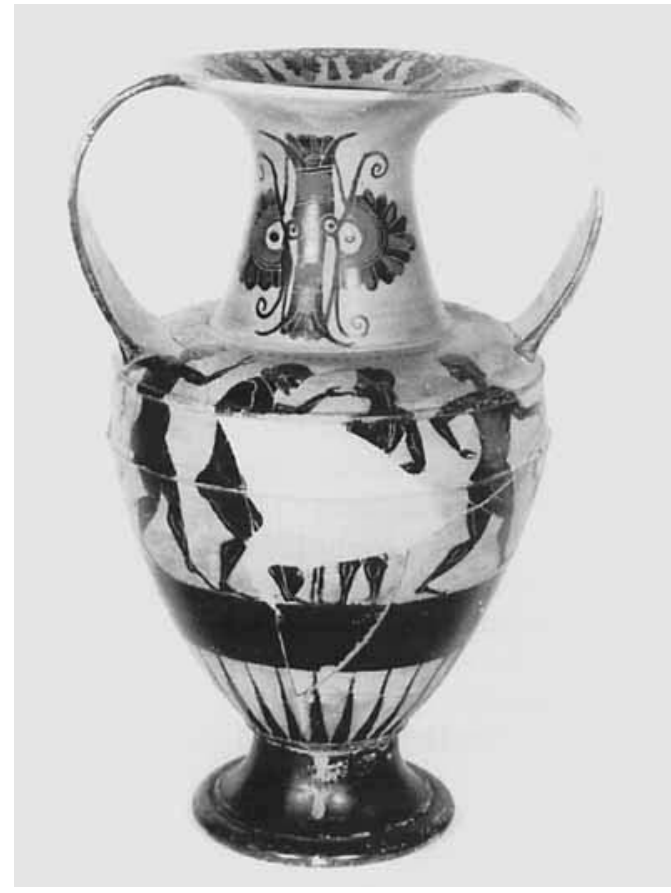

FúJRE 1. Nikosthenic amphora from Cervetri. Courtesy of Ashmolean Museum Oxford, 215. ABV 216.3.

ans in claiming that 'the activities of the Nikosthenic workshop are by no means typical' ( $c f$. Austin \& Vidal Naquet 1977: 114).

The adoption of Etruscan shapes shows that the Nikosthenic workshop produced explicitly for a foreign market. The substantial scale of its operations - it seems to have been a particularly large concern associated with a very large number of painters, employing up to 30 persons (Eisman 1974) - makes it impossible to dismiss it as an isolated experiment within a system not otherwise geared to precise marketing. A model of exchange for the 6 th century must accommodate the possibility of systematic targeting of precise foreign markets by particular exporters.

Although the imitation of shapes current in a foreign market is practically unique, there are other signs of market specialization. Comparison of different Athenian painters or workshops around $500 \mathrm{BC}$ reveals:
- exactly $50 \%$ of the 60 cups of the Tleson painter with known provenance come from Etruria, whereas only $14 \%$ of the 189 cups of the Leafless Group (FIGuRE 2) come from Etruria;

- $5.5 \%$ of 109 lekythoi of the Cock Group come from the western Greek area, as against $33 \%$ from Athens and $30 \cdot 3 \%$ from the rest of mainland Greece; but

- $69 \cdot 6 \%$ of lekythoi by the Gela Painter come from western Greece, only $18.5 \%$ from Athens and $6 \cdot 5 \%$ from the rest of the Greek mainland (Scheffer 1988: 538-9).

Scheffer suggests that the later date of the Leafless Group may sufficiently account for its different Etruscan distribution (Etruria had lost interest in black-figure cups), but the differences with regard to the lekythoi do not seem explicable that way. The Caylus Painter, a member of the Leafless Group, was important in reviving the red-figure eye cup in the late archaic period, after more than a decade in which eye cups had not been produced. That revival is best explained in terms of Etruscan demand, actual or anticipated (Williams 1988). Here is a further demonstration that we are not always dealing with particular painters or workshops which produce for a single specific market; a workshop not otherwise closely involved there might nevertheless direct a particular part of its production to a particular area.

Striking contrasts also occur in the distribution of different shapes of pot produced by the same workshop. Oinochoai and skyphoi both belong to drinking contexts, but of 64 provenanced skyphoi from the workshop of the Theseus and Athena Painters:

- 50 come from Athens (31) or the rest of Greece (19);

- 8 from west Greece;

- 6 from Etruria;

- and none from East Greece;

but of 95 oinochoai from that workshop (FIGURE 3):

- only 11 come from Athens (3) or the rest of Greece (8);

- 30 come from East Greece;

- 8 from western Greece;

- and 46 from Etruria.

Particular factors may skew the East Greek case (28 of the 30 finds are from Kamiros), but the Etruscan anomaly looks secure: 10 of the 46 are from Vulci, 18 from Spina, no other site has more than 4 (Scheffer 1988: 543). 
FIGURE 2. Cup of the Leafless group, from Kamiros. Courtesy of Ashmolean Museum Oxford, 237. ABV 643.150

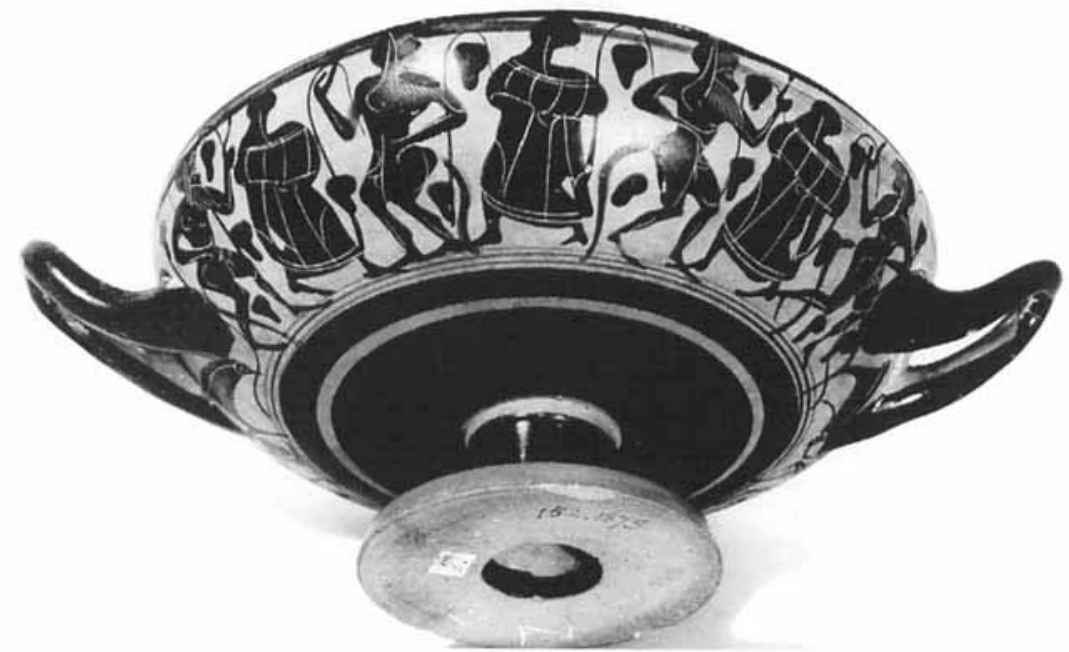

Scheffer's study, on which I have relied for these figures for late 6th- and early 5th-century patterns, concludes that shape was the most important trade factor. But in fact her work shows that there was specialization both in terms of shape and in terms of painter. Market specialization in terms of subject matter and decoration certainly also occurred, although I will not further discuss it here. Webster (1972) postulated that vases were exported second-hand in order to explain those pots found outside Athens on which there is decoration or writing more appropriate to an Athenian than a foreign context (e.g. kalos names which seem to refer to contemporary homoerotic crushes in Athens). But the distribution patterns discussed here seem to rule that out, and kalos names rather suggest that - although certain broad categories of subject were painted for a particular export market - painters were still inclined to treat subjects in detail in ways which would attract attention and critical approval in their own or in other workshops, and perhaps of Athenian passers-by (cf. Boardman 1975: 88). A separate argument against a second-hand market, based on trademarks, is made by Johnston (1979: 40-41).

The distribution of Attic pottery in the early 6th century BC is less easy to determine: the number of pots involved is much smaller, and the likelihood of being misled as to general trends much greater. However, while studies of pottery distribution in the later 6th and in the 5 th century have to use the rather partial

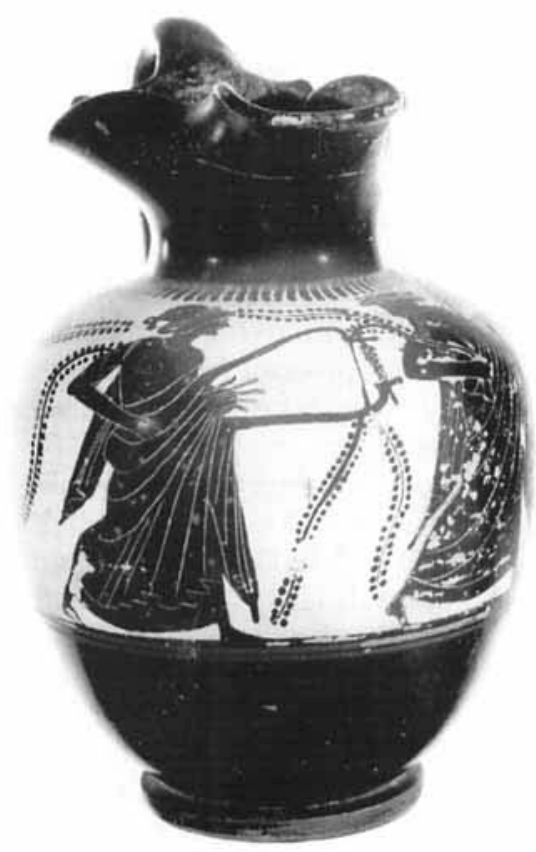

FIGURE 3. Oinochoe from workshop of the Athena Painter. Courtesy of Ashmolean Museum Oxford, 228. ABV 525.9.

data provided by Beazley in $A B V, A R V$ and Paralipomena, Rosati and his team (Rosati et 


$\begin{array}{lrrrrrrrrr}\text { site/shape } & \text { amphora oinochoe } & \text { lekanis } & \text { krater } & \text { plate } & \text { olpe } & \text { skyphos } & \text { kylix } & \text { lotal } \\ \text { Athens } & 78 & 33 & 29 & 16 & 15 & 14 & 12 & 10 & 207 \\ \text { Vari } & 3 & 5 & 27 & 0 & 3 & 1 & 2 & 0 & 41 \\ \text { Aigina } & 3 & 1 & 5 & 4 & 0 & 4 & 1 & 2 & 20 \\ \text { Naukratis } & 3 & 5 & 8 & 6 & 1 & 12 & 2 & 5 & 42 \\ \text { total } & 87 & 44 & 69 & 26 & 19 & 31 & 17 & 17 & 310\end{array}$

TABLE 1. Distribution of the most popular early 6th-century Athenian pot shapes at the sites from which 10 or more pots have been found. (After Rosati et al. 1989.)

$\begin{array}{lrrrcrr}\text { site/painter } & \text { Gorgon } & \text { KX } & \text { Sophilos } & \text { Kerameikos } & \text { KY } & \text { total } \\ \text { Athens } & 52 & 27 & 21 & 12 & 7 & 119 \\ \text { Vari } & 2 & 2 & 4 & 2 & 0 & 10 \\ \text { Aigina } & 8 & 5 & 8 & 2 & 9 & 40 \\ \text { Naukratis } & 9 & 11 & 3 & 4 & 3 & 30 \\ \text { total } & 71 & 45 & 26 & 20 & 19 & 181\end{array}$

TABLE 2. Distribution of works of the most popular early 6th-century Athenian pottery painters at the sites from which 10 or more attributable pots have been found. (After Rosati et al. 1989.)

al. 1989) have substantially supplemented the data-base which $A B V$ provides. Hannestad (1989: 114-15, 125-7) has shown that in $A B V$ Beazley systematically identifies fewer painters' hands on cups than on amphorae, and that his Etruscan data seriously understate the proportion of cups and also of lekythoi. Rosati et al. go some way to removing such bias, although no modern statistics can finally cope with the unreliability of claims of provenance for many objects in museums.

Most Athenian pottery manufactured in the first quarter of the 6th century has been found in Athens and Attica. Outside Attica only two places, Aigina and Naukratis, have yielded more than 10 pots. Yet the distribution of shapes is sensibly different at different sites (TABLE 1). The differences between Athens and Vari, near by in Attica, are probably influenced by the fact that the Vari evidence is entirely from a cemetery, the Athens evidence culled from various contexts. The Naukratis evidence probably includes no cemetery material. It is less easy to see that find context can account for the very different emphasis in the Aigina and Naukratis material. The Naukratis finds seem predominantly sympotic: kylikes, olpai, krateres and oinochoai are more popular than plates, amphorae or skyphoi, although lekanides are surprisingly popular. It is difficult to find any single rationale for the distribution of the rather small quantities of pottery found on Aigina, which may be partly a result of both Aigina town and Aphaia sanctuary material being included in the Aigina totals.

A similar picture emerges from examining painter rather than shape (TABLE 2). The small showing of the KY painter at Vari is unsurprising since he(?) is mainly a cup-painter; but this will not explain why the $\mathrm{KX}$ painter, whose lekanides are found even more commonly than his cups outside Attica, is not better represented at Vari; nor why the KY painter is more popular than $\mathrm{KX}$ on Aigina while the reverse is true at Athens and Naukratis.

A test on one painter and one site indicates that part of the pattern results from variations in attribution, and in the thoroughness of collection. Bakir's 1981 monograph on Sophilos, not known to Rosati et al. (1989), yields the distribution of pots by Sophilos and his 'circle' over the four sites shown in TABLE 3 . Sophilos is now more common, rather than less, in Naukratis (FIGURE 4) than at Vari or Aigina, and only in the case of Athens is the number of pots identified the same. Nevertheless, the basic pattem is similar, with predominantly local distribution of Sophilan pots: 32 of the 59 Sophilan pots for which Bakir gives a prov- 
site/painter Sophilos Circle of Sophilos total

$\begin{array}{lrrr}\text { Athens } & 7 & 14 & 21 \\ \text { Vari } & 0 & 1 & 1 \\ \text { Aigina } & 3 & 1 & 4 \\ \text { Naukratis } & 4 & 3 & 7 \\ & & & \\ \text { total } & 14 & 19 & 33\end{array}$

TABLE 3. Distribution of works of Sophilos and his circle. (After Bakir 1981.)

$\begin{array}{lcccccc}\text { site/painter } & \text { Gorgon } & \text { KX } & \text { Sophilos } & \text { Kerameikos } & \text { KY } & \text { total } \\ \text { Naukratis } & 14 & 11 & 11 & 5 & 4 & 45\end{array}$

TABLE 4. Finds at Naukratis of works of early 6th-century Athenian pot painters. (Data courtesy of Astrid Möller.)

enance come from Athens or Attica. Möller's forthcoming monograph on Naukratis will give the distribution of the relevant painter's wares found there shown in TABLE 4. Only one of the actual numbers is that given by Rosati, but only in the case of Sophilos is the variation significant (even since Bakir's monograph the number of recognized Sophilan vases in the Naukratis material has substantially increased): the overall pattern is not seriously changed. These tests reveal that any single number is liable to significant revision, but that relatively rarely will such revisions alter overall patterns.

For the west, numbers of pots from a single site are ton small in this period to allow detailed conclusions, but regional patterns are of interest. Not only does the distribution pattern in western Etruria differ from that in any site analysed above, but there is a marked difference between that area and Sicily or Magna Grecia (TABLE 5). This difference is reflected in the distribution of pots by major painters (TABLE 6): the better showing of the Gorgon painter in Etruria no doubt correlates with his production of amphorae.

For the period $575-C .550$ BC the number of pots for analysis is greater. Analysis by shape of pots from sites yielding more than 10 pots (TABLE 7 and FIGURE 5) shows totally 'aberrant' patterns of pot shape at two of the three sanctuary sites, Brauron and Tocra. The unexpected distribution of shapes at the Tocra sanctuary of Demeter encouraged Boardman to think that dedicants there had to make do with whatever the tramping vessel which visited them happened to have left (Boardman 1968), but that

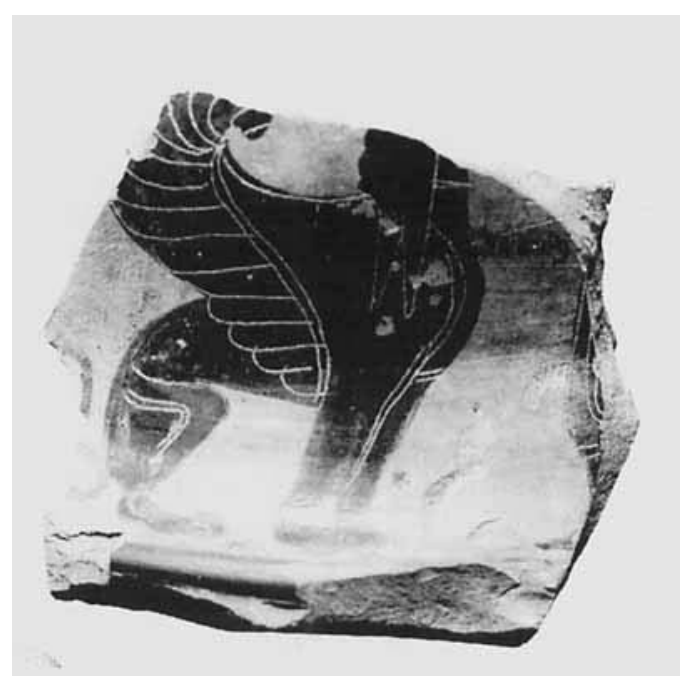

FIGURE 4. Fragment ascribed to Sophilos' workshop, from Naukratis. Courtesy of Ashmolean Museum Oxford, 128.20. ABV 38.4.

explanation will not work for the sanctuary of Artemis at Brauron in Attica (from which, it must be admitted, only a tiny proportion of the finds have been published): the Tocra pattern might best be regarded as the product of peculiar demand rather than peculiar supply. The Perakhora sanctuary distribution concentrates more single-mindedly than anywhere else on drinking vessels, kylikes and skyphoi, but is quite like many non-sanctuary distributions. The contrast between Sicily and Magna Graecia on the one hand, where sites such as Selinous or 'Taras or Cumae predominantly receive $k v$ likes, and Etruria on the other, where sites such 


$\begin{array}{lrrrrrrrr}\text { site/shape } & \text { amphora } & \text { oinochoe } & \text { lekanis } & \text { krater } & \text { olpe } & \text { skyphos } & \text { kylix } & \text { total } \\ \text { Athens } & 78 & 33 & 29 & 16 & 14 & 12 & 10 & 192 \\ \text { Tyrrhenian Etruria } & 22 & 1 & 2 & 0 & 2 & 0 & 11 & 38 \\ \text { Magna Grecia } & 2 & 3 & 2 & 0 & 0 & 1 & 5 & 13 \\ \text { Sicily } & 1 & 0 & 0 & 1 & 0 & 2 & 6 & 10 \\ \text { total } & 103 & 37 & 33 & 17 & 16 & 15 & 32 & 253\end{array}$

TABLE 5. Distribution of the most popular shapes of early-6th-century Athenian pottery. (After Rosati et al. 1989.)

$\begin{array}{lrrrrrr}\text { site/painter } & \text { Gorgon } & \text { KX } & \text { Sophilos } & \text { Kerameikos } & \text { KY } & \text { total } \\ \text { Athens } & 52 & 27 & 21 & 12 & 7 & 119 \\ \text { Tyrrhenian Etruria } & 10 & 6 & 2 & 0 & 5 & 23 \\ \text { Magna Grecia } & 2 & 3 & 0 & 1 & 0 & 6 \\ \text { Sicily } & 0 & 1 & 0 & 0 & 3 & 4 \\ \text { total } & 64 & 37 & 23 & 13 & 15 & 152\end{array}$

TABLE 6. Distribution of work of early-6th-century Athenian pot painters. (After Rosati et al. 1989.)

\begin{tabular}{|c|c|c|c|c|c|c|c|c|c|c|c|}
\hline site/shape & kylix & amphora & lekanis & plate & skyphos & krater & hydria & pyxis & Iouterion & dinos & total \\
\hline Aigina & 3 & 9 & 2 & 3 & 0 & 9 & 1 & 2 & 0 & 3 & 32 \\
\hline Athens & 60 & 36 & 35 & 33 & 22 & 16 & 12 & 8 & 8 & 7 & 237 \\
\hline Brauron & 0 & 0 & 0 & 12 & 0 & 0 & 0 & 1 & 0 & 0 & 13 \\
\hline Caere & 7 & 35 & 0 & 0 & 0 & 0 & 4 & 0 & 0 & 0 & 46 \\
\hline Corinth & 25 & 1 & 0 & 2 & 4 & 0 & 1 & 1 & 0 & 0 & 34 \\
\hline Cumae & 11 & 0 & 1 & 0 & 0 & 0 & 0 & 0 & 0 & 0 & 12 \\
\hline Delos & 4 & 3 & 1 & 1 & 0 & 0 & 4 & 0 & 0 & 0 & 13 \\
\hline Eleusis & 8 & 1 & 2 & 1 & 0 & 0 & 1 & 0 & 2 & 0 & 15 \\
\hline Ialysos & 6 & 6 & 0 & 1 & 0 & 0 & 0 & 0 & 0 & 0 & 13 \\
\hline Kamiros & 6 & 2 & 1 & 0 & 0 & 0 & 2 & 0 & 0 & 0 & 11 \\
\hline Kavala & 10 & 0 & 3 & 1 & 0 & 0 & 0 & 0 & 0 & 0 & 14 \\
\hline Marseilles & 4 & 17 & 2 & 0 & 0 & 9 & 0 & 0 & 0 & 3 & 35 \\
\hline Megara Hyblaia & 14 & 3 & 0 & 2 & 1 & 5 & 1 & 1 & 0 & 1 & 28 \\
\hline Naukratis & 24 & 6 & 8 & 4 & 1 & 4 & 0 & 0 & 0 & 2 & 49 \\
\hline Perakhora & 24 & 1 & 0 & 0 & 16 & 0 & 0 & 0 & 0 & 0 & 41 \\
\hline Selinous & 14 & 0 & 0 & 0 & 0 & 0 & 0 & 0 & 0 & 0 & 14 \\
\hline Taras & 57 & 8 & 0 & 0 & 2 & 0 & 1 & 0 & 0 & 0 & 8 \\
\hline Tell Sukas & 2 & 1 & 0 & 0 & 0 & 4 & 4 & 0 & 0 & 2 & 13 \\
\hline Thasos & 43 & 1 & 2 & 0 & 0 & 1 & 0 & 0 & 0 & 1 & 48 \\
\hline Tocra & 5 & 1 & 12 & 10 & 1 & 1 & 2 & 0 & 0 & 0 & 32 \\
\hline Vulci & 8 & 29 & 0 & 0 & 0 & 0 & 5 & 0 & 0 & 0 & 42 \\
\hline otal & 335 & 160 & 69 & 70 & 47 & 49 & 38 & 13 & 10 & 19 & \\
\hline
\end{tabular}

TABLE 7. Distribution of most popular Athenian pot shapes of the years c. 575-550 BC across sites in the Mediterranean at which 10 or more Athenian pots of the period are recorded. (After Rosati et al. 1989.)

as Vulci or Caere predominantly receive amphorae, is marked. Marseilles seems at first sight to repeat the Etruscan pattern, but the relatively high number of krateres and dinoi, and the absence of hydriai, suggests distinct market preferences. Among other features of note, out- side Athens the only sites receiving a significant proportion of their pottery in the form of lekanides are Naukratis and Tocra, and the only sites receiving a significant proportion of their pottery in the form of skyphoi are Perachora and Aigina; Kavala and Thasos in the north 


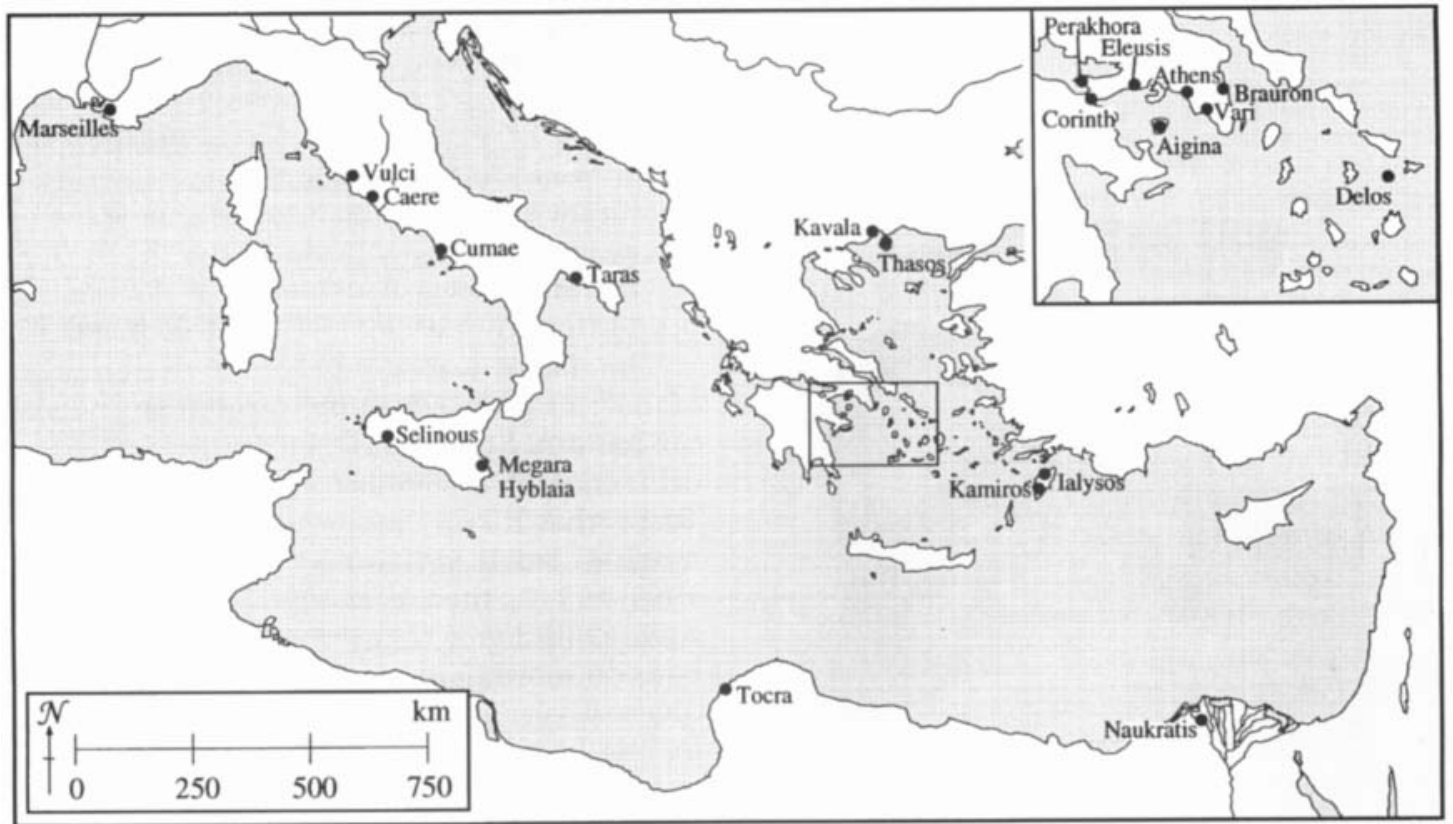

FIGURE 5. Sites mentioned in TABLES 1-8.

\section{site/painter Polos C London Kleitias Heidelberg Griffin Nearkhos Akropolis Akropolis total n B76 $606 \quad 627$}

\begin{tabular}{|c|c|c|c|c|c|c|c|c|c|c|}
\hline Aigina & 19 & 2 & 0 & 0 & 0 & 0 & 0 & 0 & 0 & 21 \\
\hline Athens & 86 & 43 & 10 & 8 & 6 & 5 & 5 & 4 & 4 & 171 \\
\hline Brauron & 4 & 0 & 0 & 0 & 0 & 0 & 0 & 0 & 0 & 4 \\
\hline Caere & 2 & 4 & 2 & 0 & 0 & 0 & 1 & 0 & 0 & 9 \\
\hline Corinth & 3 & 15 & 0 & 0 & 2 & 4 & 0 & 0 & 0 & 24 \\
\hline Cumae & 0 & 9 & 0 & 0 & 1 & 2 & 0 & 0 & 0 & 12 \\
\hline Delos & 11 & 3 & 0 & 0 & 1 & 0 & 0 & 0 & 0 & 15 \\
\hline Eleusis & 4 & 8 & 4 & 0 & 0 & 1 & 0 & 0 & 0 & 17 \\
\hline Ialysos & 1 & 5 & 0 & 0 & 1 & 0 & 0 & 0 & 0 & 7 \\
\hline Kamiros & 1 & 1 & 1 & 0 & 3 & 0 & 0 & 0 & 0 & 6 \\
\hline Kavala & 4 & 6 & 0 & 0 & 2 & 0 & 0 & 0 & 0 & 12 \\
\hline Marseilles & 5 & 0 & 1 & 0 & 0 & 1 & 0 & 0 & 0 & 7 \\
\hline Megara Hyblaia & 1 & 4 & 0 & 0 & 4 & 0 & 0 & 0 & 0 & 9 \\
\hline Naukratis & 10 & 11 & 1 & 5 & 2 & 3 & 0 & 0 & 0 & 32 \\
\hline Perakhora & 0 & 7 & 0 & 0 & 3 & 0 & 0 & 0 & 0 & 10 \\
\hline Selinous & 0 & 4 & 0 & 0 & 8 & 1 & 0 & 0 & 0 & 13 \\
\hline Taras & 0 & 36 & 1 & 0 & 7 & 12 & 0 & 0 & 0 & 56 \\
\hline Thasos & 2 & 36 & 0 & 0 & 1 & 0 & 0 & 0 & 0 & 39 \\
\hline Tocra & 27 & 2 & 0 & 0 & 0 & 2 & 0 & 0 & 0 & 31 \\
\hline Vulci & 0 & 3 & 1 & 1 & 1 & 1 & 1 & 0 & 0 & 8 \\
\hline total & 180 & 199 & 21 & 14 & 42 & 32 & 7 & 4 & 4 & 503 \\
\hline
\end{tabular}

TABLE 8. Distribution of work of most popular Athenian pot painters of the years c. 575-550 BC across sites of TABLE 7. (After Rosati et al. 1989.)

Aegean both predominantly receive kylikes with lekanides the next most popular shape; Tell Sukas in the Levant has a preference for krateres and hydriai, unparalleled elsewhere.
The distribution of the works of particular painters largely reflects the same patterns ( $\mathrm{T}^{\mathrm{A}}$ BLE 8). The C painter is well represented where cups predominate (Taras, Thasos, Corinth, 


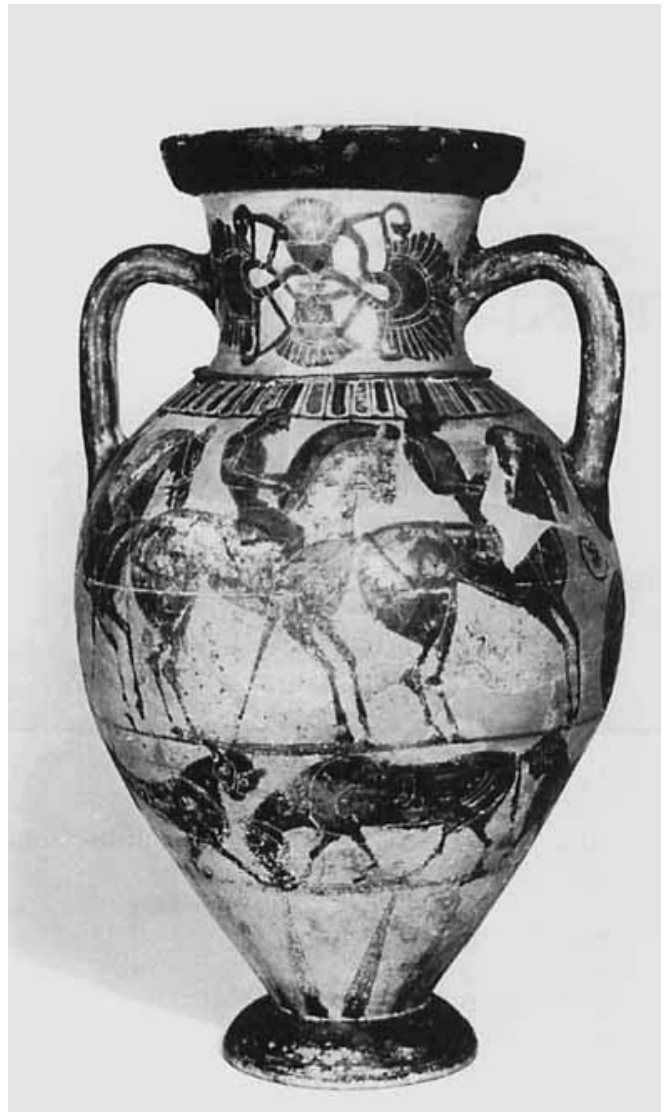

FIGURE 6. Tyrrhenian amphora. Courtesy of Ashmolean Museum Oxford, 1913.164. ABV 100.64 .

Cumae), but not in Etruria or Marseilles where amphorae dominate the assemblage. The work of some painters (painters known after pots found on the Athenian Acropolis) is found only at Athens, of others only at Athens and in Etruria (Nearkhos) or at Athens, Naukratis and Etruria (Kleitias). Works by the Griffin painter get to Corinth, Sicily, Magna Graecia, Naukratis and Tocra but not to the eastern or northern Aegean. Cups by the Heidelberg painter reach almost all parts, except some places close to Athens (Aigina, Eleusis): they are quite numerous in Sicily (both at Megara Hyblaia and at Selinous), but make little impact in Etruria or at Marseilles. The Polos painter, who dominates the Athens assemblage, is similarly dominant only at Tocra,
Marseilles, Aigina and Delos although a major presence at Naukratis, Kavala and Eleusis. The significant presence of works by the Polos painter at Marseilles contrasts with their absence from Sicily and Magna Graecia and insignificant representation in Etruria; the showing at Kavala contrasts with the insignificant representation at near-by Thasos (the published proportion from each site is, however, small).

The statistics are crude, and re-examination of the pots from a site might significantly alter the pattern. Stucchi (1984a; 1984b) argued, of differences in assemblage between Cyrene and Tocra, that it was important not to make too much of small variations (but see Boardman 1994: 145-7); there is enough pattern to justify some confidence that the distributions noted here do more than map the attributive prejudices of various scholars. The small samples for the first half of the 6th century suffice to show that neither shapes nor products of particular painters or workshops are randomly distributed; different places generated different demands, characteristically met by different workshops.

Hannestad (1989: 130) suggested that traders tramped round the Mediterranean showing off their wares at every port on their route - it just happened that particular shapes, or the work of particular painters, were only acquired in certain places. The clarity with which patterns emerge, even from our deficient data, along with the Nikosthenic phenomenon, makes this the least economical of hypotheses. Johnston (1979: 51, cf. 12), has argued from the distribution of marks, rather than of pot shapes, that 'At least down to the latest 6th century there seems to have been little stopping-off to sell vases en route to Etruria: we would have expected more main-line marks on pieces found in Campania and Sicily had this occurred.' Evidence from shipwrecks, although confirming that tablewares never made up a whole cargo (Parker 1992: 16), offers little further illumination. Most wrecks of the period seem dominated by commodities of one particular origin (e.g. Parker 1992: no. 106); the Giglio Campese A wreck (Parker 1992: 451) may give evidence for one ship carrying pots from a variety of origins but with a bias towards a particular shape (aryballoi of Etruscan manufacture and aryballoi from the Early Corinthian Jewel Painter workshop are both reported). 
The Nikosthenic workshop potted shapes specifically designed to meet the demands of a particular market. Either other potters too, on this evidence, were already by $c .600 \mathrm{BC}$ producing with a particular market in mind, or particular traders acquired pots, produced with no particular market in mind, in order to meet the known preferences of familiar clients. That potters produced for a particular market at a slightly later date is suggested by the Etruscan painted inscription on a 5 th-century Attic red-figure cup from Populonia. For Gill (1987), 'The application of an Etruscan inscription in an Attic workshop for an Etruscan client is unlikely'; he favours Attic clay having been exported to Etruria where the pot was then made. $\mathrm{He}$ cites the parallel case of Chiot pots at Naukratis on which dedicatory messages have been written before firing, where transport of the Chiot clay has been suggested. On the view adopted here, both inscriptions would come from one end of the spectrum of specificity of order. The strongly patterned distributions, and phenomena such as the Tyrrhenian amphorae (FIGURE 6), make it highly likely that, whatever most potters knew of the places where their pots would end up, they knew very well what particular traders who visited their workshops wanted to acquire, and produced accordingly.

The direction of pots to a particular market was probably not new in $600 \mathrm{BC}$ : the marked discrepancy between the Greek pottery assemblage at Pithekoussai in the 8th century and the Greek pottery known from Veii in Etruria during the same period ( $c f$. Ridgway 1992: 129 38) argues for directional exhange in pottery even at that date. Indeed there seems some evidence of Euboean and Corinthian potters moving to set up workshops in Etruria, Campania, and at Pithekoussai (Williams 1986; Ridgway 1992: 131-3, 136). Even the markedly eastward distribution of Euboian pendent-semicircle plates (as opposed to skyphoi) in the 8th century may represent response to a particular eastern demand (cf. Coldstream 1994: 47 and Lemos' map in Popham 1994: 27).

Pots were not themselves an export of great economic significance. It is not the fact that pots were exchanged that is important, but the way in which they were exchanged; and the proportion of pots originally exchanged represented by our surviving sample is not an issue (but see below). The pattern of distribution of pots is the more significant because the pots were not intrinsically valuable: the pattern of exchange to which they attest cannot have been created by the demand for pottery. The ways in which different places receive different shapes of pot and works by different painters cannot adequately be accounted for by models of exchange which regard tramping as the predominant mode of trade or which assume that all other goods move on the back of agricultural goods being exchanged to match local deficits with local surpluses. Both phenomena demand regular, and in most cases direct, trading links between Athens and individual ports around the Mediterranean (though nothing demands that these links were in the hands either of Athenians or of men from the destination port). Regular trading links presuppose more or less consistent exchange patterns, not the capricious patterns which are the product of periodic agricultural crisis. If pots are moving on the back of some other good then that good must be something more or less constantly in demand, and in sufficient demand to maintain regular links. If that good is an agricultural product then it must be an agricultural product grown to be exchanged and not for subsistence, and we must assume that agricultural production too was shaped by particular distant demands. The existence of a regular network of direct trading links between Athens and a large number of Mediterranean ports has implications for the total volume of trade and for its economic significance, since maintaining a network requires a certain minimum density of contact; that significant total volume of trade and that network constitute a prima facie case for envisaging a 'conglomeration of interdependent markets'.

This model for the exchange of pottery, where producer and/or middleman have a more or less shrewd idea of who they are producing for, resembles the model which Anthony Snodgrass (1983) suggested a decade ago for archaic Greek trade in stone and, in part at least, for trade in metals - and therefore for a very large tonnage of shipping. Large-scale movement of stone. may be predominantly a phenomenon of the 6 th rather than the 8 th or 7 th centuries, but large-scale movement of metal ores and ingots was almost certainly a feature of the 8 th as well as of later centuries. Glenn Markoe (1992: 71) has suggested that: 
The relatively finite time period marking the occurrence of Phoenician imports in central Italy ... suggests a period of intense and directed commercial activity on the part of the Phoenician merchant. ... The sheer number and distribution of silver objects of Phoenician manufacture found in central Italy at this time and the concurrent appearance on Cyprus and Rhodes of related silverwork of Phoenician origin point to a consistent conclusion: it was silver that was the primary metal commodity sought by the Phoenician trader in Italy.

(Compare Gill (1988) on demand for copper creating directional trade with Cyprus, with particular reference to the period of the Peloponnesian war.) Just as it is very likely to have been metals which lured Greeks west out of the Aegean, so too it may well be the directed exchange of metals which created the model by which exchange of manufactured goods, such as pottery, developed.

\section{The question of volume}

The model of directional exchange dominating the exchange patterns of the archaic Greek world outlined above has implications for the scale of the activity. It would be hard to credit market sophistication in the pottery trade if at its height Etruria was only receiving some 60 pots a year (Gill 1991: 36, cf. 42). That low figure is for surviving pots; although the relationship between surviving and vanished pots is uncertain - Cook's (1959) suggested multiplier of 400 seems as likely to be too low as too high (Gill 1991: 36-7 n. 72) - the actual number of pots imported annually in the late 6th century seems unlikely to have been smaller than 6000 , and may have been closer to 25,000. Gill believes in a high percentage of imports surviving because the Etruscans used imported pottery primarily as grave goods, but Hannestad (1989) has offered cogent arguments against that claim.

But if directional exchange demands a dense network of exchange, how significant was such a network within the economy as a whole? To explore this, I turn to rather different evidence usefully independent of the pottery discussed above.

Greeks settled on the Italian island of Ischia, anciently called Pithekoussai, shortly before 750 BC. The site has been extensively explored by archaeologists, particularly since the 1950s, and some 1300 graves have been excavated. David Ridgway, long involved in the excavations, has recently been spurred on by Ian Morris' (1987: 166) calculation that the population of Pithekoussai was 4000-5000 in $700 \mathrm{BC}$, to make calculations of his own: he suggests the burials made in the cemetery between 750 and 700 numbered between 9860 and 19,720, corresponding to a living population at any time between 750 and 700 of between $c .5000$ and c. 10,000 (Ridgway 1992: 101-3). There are, as Ridgway emphasizes, questionable assumptions built into this estimate, but it seems unlikely to be the wrong order of magnitude.

How do we account for the Greek population of Pithekoussai rocketing from 0 to 5000, or more, in a quarter of a century or so? Scholars (as Morris 1987: 166) sometimes write of Pithekoussai as if it were a deliberate official joint colonial foundation by Eretria and Khalkis, but neither the literary tradition, which simply says that 'Pithekoussai was once inhabited by Eretrians and Khalkidians' (Strabo 5.4.9), nor the archaeological remains encourage the view that men were sent out specifically to found a new city. The agricultural resources of Pithekoussai, restricted today, are likely to have been restricted in antiquity. Getting the most out of the volcanic soils, which are most suitable for vines, demands considerable landscape management - not an evident priority among 8thcentury settlers. Ridgway (1992: 34) has stressed that 'the 8th-century Euboeans of Pithekoussai were intent on trade and industry'; in the current state of our knowledge it seems more probable that Pithekoussai was an opportunist settlement, formed because well placed to achieve certain desired aims, which centred on the exchange of goods, by those whose own personal interests were most intimately tied up with that exchange of goods, than that it was formally sent out, under a designated founder and as a new polis, by 'mother cities' in Euboia.

With this background, Pithekoussai is hardly likely to have been populated in a single expedition, by some flotilla carrying 2000 or more persons. Rather, individuals and small groups moved piecemeal to Pithekoussai because they perceived it to be in their interests to do so, remaining there (not necessarily uninterruptedly) until death because they saw no reason to think their perceptions incorrect. Getting Greek bodies to Pithekoussai in these numbers will have demanded a large number of ship journeys (we can hardly think of more than 50 
passengers per pentekonter (Humphreys 1978: 166-8 and Snodgrass 1983: 16-17)): maintaining them profitably will have demanded more still. It is hard to imagine how Pithekoussai could have acquired or sustained a population near Ridgway's estimate unless the sailing season saw its port a hive of activity and its contacts with mainland Greece and elsewhere were regular and frequent. How regular and frequent remains a matter of guesswork, so let me hazard a guess (if this guess is out by a factor of two the argument is unaffected): I think we are dealing with around 50 ship-journeys per year between Pithekoussai and the mainland Greek world (plus other journeys to metal-rich areas to collect raw materials). Those 50 ship-journeys might involve 15-20 ships sailing back and forth, with 750-1000 men rowing them, if merchant galleys, or a rather smaller number (100-200) crewing them if they were sailing vessels, and perhaps 3500-4000 tons of goods being moved (for ships of $c .75$ tons see André \& Baslez 1993: 421). However much we emphasize the 8th-century opening-up of the Mediterranean world to the Greeks and the revolution in metal use and consumption, however much we see the population of Pithekoussai as having the peculiar advantages of being in the right place at the right time, Pithekoussai must demonstrate the possibility of regular, frequent and - I would suggest directional, long-distance trade as early as the third quarter of the 8th century. Archaeologically such a pattern of exchange would seem to belong to the world in which Hesiod and Homer flourished.

\section{The literary evidence}

To what extent is this archaeological picture supported by literary sources? Hesiod's statement to his brother Perses of c. $700 \mathrm{BC}$ runs: 'If ever you turn your misguided heart to trading and wish to escape from debt and joyless hunger, I will show you the measures of the loudroaring sea' (Works and Days 646-8). This remark, often quoted for the view that Hesiod sees shipping as a supplement to agriculture, comes from a much longer passage about the right time and context for sailing. Hesiod, in stressing the importance of sailing only during the correct season, also stresses that one might trade not in order to survive but in order to make a gain: 'You yourself wait until the right season for sailing is come and then drag a swift ship down to the sea and load it with a fitting cargo in order that you may bring home profit [kerdos]' (Works and Days 630-32). He repeats this when, in a much-discussed phrase, he advises Perses to "praise a small ship, but put cargo on a large one; the larger the cargo the greater profit [kerdos] will be added to profit, if only the winds keep away harmful gales' (Works and Days 643-5). These lines have been interpreted as advice to join with other contributors in the load of a large ship, but the mention of profit seems relevant only if the greater profit is going to accrue to Perses, that is, if the whole cargo of the larger ship is his. Commenting on the limited possibilities of sailing in the spring, Hesiod does not advise a sailing trip snatched then: men do so 'because goods [khremata] are life for wretched mortals', a phrase which seems to imply men who have trade as their whole livelihood, not a supplement to agricultural activities.

Hesiod's final advice about trade by sea is to put not all one's goods in ships but only the smaller part. Significant here is the plural 'ships': Hesiod does not advise spreading one's cargo around a number of ships or making sure that only part of the cargo of any one ship belongs to you, he is thinking of entrusting all one's goods to ships at the same time, not just because of the risks at sea but because of the risks involved taking the goods by waggon to the sea in the first place (for the sense of 692 see West 1978: 326). West maintains, 'For Hesiod [going to sea] is not an alternative way of life to agriculture but an optional supplement to it' (West 1978: 313), but these lines actually display an awareness of the possibility of trade providing an alternative life-style, one that can be sustained in parallel with farming but is also pursued single-mindedly by others. The stress on profit strongly suggests more than the simple getting-rid of a surplus that has no local market or meeting a local deficit: the temptation to entrust all one's goods to a ship is the temptation of one wholly involved in, and dependent upon, long-distance trade. If some who engaged in trade were poor and desperate, this passage gives good reason to believe that not all were - others might own and load up large ships, make even larger profits.

The world of the Homeric Odysseus, too, is a world in which men are continually on the 
move in search of profit. The lying tales with which Odysseus repeatedly conceals and protects his own identity crucially depend upon the displaced person being an entirely familiar phenomenon - murderers, piratical adventurers, soldiers in search of employment, nobles who feel no obligation to report why they are on the move, Odysseus introduces us to them all (Odyssey 13.256-73, 14.199-228, 17.419$44,24.304-8)$. In this world, men can go down to the coast on the off-chance of picking up a ship to a favourable destination, as Theoklymenos does (Odyssey 15.222-81). But the constant moving of men around the world, a feature as much of Iliad as of Odyssey, even if it has not the same structural importance in the Iliad (see e.g. Iliad 2.661-7, 9.447-84, 13.694-6, 15.430-32, 16.571-4, 23.85-90 for some Iliadic expatriates), is not a random, Brownian, motion. Men move not only because they have to, but because they make a profit by doing so. Euryalos taunts Odysseus that his reason for not competing in the athletics is that he is no athlete but 'a leader of sailors who are merchants, a man who knows about cargo and keeps an eye on saleable goods and attractive profits' (Odyssey 8.161-4); the gibe gains its force by its probability. Merchants not infrequently end up at a place with which they are not familiar, yet they do have a destination in mind, as Euenos son of Ieson had Troy in mind as the destination for shiploads of wine from Lemnos which the Akhaians exchanged for bronze, iron, hides, oxen and slaves (Iliad 4.46775). The fictional Phoenician, whom the lying Odysseus claims persuaded him to sail with him to Libya on the grounds that 'I would get a cargo', had a destination in mind - at which he could sell him for an immense price (Odyssey 14.293-7). Goods bought from Phoenician merchants may be classed as 'trinkets' (Odyssey 15.416), but the sellers had made a choice of preferred market, even if they are open to taking the sort of windfall which seducing a fellow Phoenician woman gave, at the price presumably of never returning, to the merchants who ended up running off with Eumaios (Odyssey 15. 415-84).

Neither the world of Odysseus nor the world of Hesiod would find the Demaratos of Dionysios of Halikarnassos (Roman Antiquities 3.46) an unrecognizable creature: 'There was a certain Corinthian, Demaratos by name, of the Bacchiad family, who chose to engage in commerce and sailed to Italy in his own ship with his own cargo. He sold the cargo in the Tyrrhenian cities, the most flourishing in all Italy at that time, and gained a large profit from it; after that he had no further wish to put in at other ports but he continued to sail the same route, carrying Greek cargo to the Tyrrhenians and Tyrrhenian cargo to Greece, and as a result he gained great wealth.'

\section{Conclusion}

The aim of this paper has been to demonstrate two points:

- The exchange of goods in the archaic Greek world was not dominated by the need to meet occasional shortfalls in agricultural production. The distribution of pottery through the Mediterranean is inexplicable by any model which sees exchange as occasioned by intermittent and opportunistic movement of agricultural produce;

- Not only the ancient economy of classical Greek and later times but already the archaic Greek economy was marked by a 'conglomeration of interdependent markets' in which production and prices in producing and consuming cities were linked. In structure, if not in scale, the archaic Greek economy was essentially like the classical Greek economy - and indeed like the late Bronze Age economy in which, according to Cline (1994: 106), 'Trade was primarily directional to the major palatial centers of the Aegean.'

Literary sources do not justify the belief that trade was normally opportunistic, the distribution of pottery demonstrates directional trade, and both the distribution of pottery and the remarkable growth and maintenance of the immigrant population on Pithekoussai require us to believe that the network of exchange within the Greek world was dense. Frequent and regular shipping links moved a large tonnage of goods; agricultural products will have moved both regularly and irregularly (cf. Herodotos 7.147), but a significant proportion of cargoes will have been non-agricultural, even if the proportion that were manufactured remains beyond conjecture. On the parallel of the exchange of pottery, most merchants were either equipped with specific orders or had a specific market in mind; they were not opportunists, hoping to end up, 
as Kolaios of Samos did (Herodotos 4.152), at a 'virgin' port with unsuspecting natives willing to pay extravagant prices for exotic gewgaws. Piracy existed not simply on the off-chance of capturing some produce that might prove saleable somewhere, but in the certainty of being able to supply known demand for the purchase of human labour; so also merchants worked within a known and familiar network of supply and demand.

Purcell (1990) has emphasized the high degree of mobility within the archaic Greek world. That mobility, so often appearing merely casual in the anecdotes of our literary sources, demanded a density of intercommunications which can only have been supported by regular and frequent movement of goods between pre-designated destinations. Characters like Arion, the poet passenger thrown into the sea by the Corinthian merchants with whom he is travelling and then carried to shore by a dolphin, entertain us and catch our imagination, but it is those who transported such people around the Greek world who were significant in terms of the economy.

\section{References}

ANDR6́, J.-M. \& M.-F. BASLË.. 1993. Voyager dans l'antiquité. Paris: Fayard.

ARAMAT, K. \& C.A. MORGAN. 1994. Athens, Etruria and the Heuneberg: mutual misconceptions in the study of Greekbarbarian relations, in Morris (ed.): 108-34.

Austin, M.M. \& P. VIDAL-NAOUIST. 1977. Economic and social history of ancient Greece. London: Batsford.

BAKIK. G. 1981. Sophilos; ein Beitrag zu seinem Stil. Mainz: Zabern.

BOARDMAN, J. 1968. Reflexions on the Greek pottery trade with Tocra, in F. Gadallah (ed.), Libya in history: 89-91. Benghazi: University of Libya, Faculty of Arts.

BOARDMAN, J. 1975. Athenian red-figure vases: the archaic period: a handbook. London: Thimes \& Hudson.

1979. The Athenian pottery trade: the classical period, Expedition 21: 33-9.

1994. Settlement for trade and land in North Africa, in Tsetskhladze \& Do Angelis (ed.): 137-49.

BRavo, B. 1977. Remarques sur les assises sociales, les formes $\mathrm{d}^{\dagger}$ organisation et la terminologie du commerce maritime grec à l'ćpoque archaïque, Dialogues d'Histoire Ancienne 3: $1-59$.

CARTLEDCli, P.A. 1983 'Trade and politics' revisited: Archaic Greece, in Garnsey et al. (ed.): 1-15.

Christiansen, j. \& T. MLLANimis (ed.). 1988. Ancient Greek und related pottery: 175-85. Copenhagen: Nationalmuseet.

CLINE, E. 1994 Sailing the wine-dark sea: international trade and the late Bronze Age Aegean. Oxford: British Archacological Reports. International series 591.

ColDSTREAN, J.N. 1994. Prospectors and pioneers: Pithekoussai, Kyme and central Italy, in Tsetskhladze \& De Angelis (ed.): $47-59$.

Cook, R.M. 1959. Die Bedeutung der bemalten Keramik für den griechischen Handel, Jahrbuch des Deutsches Archäologisches Instilut 74: 114-23.
Directional exchange in itself is equally consistent with 'primitivizing' and 'modernizing' models of the archaic Greek economy, at least if the bulk of shipped goods was moved to predesignated buyers. The spirit of the model advanced here is hardly primitivist, for it asserts both the large volume of goods regularly exchanged and the independence of the exchange network from agricultural vagaries. The established network effected the movement of agricultural goods at times of local crisis, but the network itself must have been created to move goods whose supply and demand were very much more consistent. That network implies interdependent markets, and should be assigned a place with the other transformations that mark the revolution of the 8 th century BC.

Acknowledgements. This paper was written at the request of Anthony Courakis for a conference at Delphi in 1995. 1 am grateful to him and to John Boardman, David Gill, Peter Haarer, Andrew Sherratt and Anthony Snodgrass for comments on an earlier draft, and to referees for sharpening up both my arguments and my prose. I owe particular thanks to Astrid Moller who not only read and criticized a draft but kindly put her data from Naukratis at my disposal.

Eisman, M.M. 1974. Nikosthenic amphorae: the J. Paul Getly Muscum Amphora, The J. Paul Gotty Museum Joumal 1: $43-54$.

FINLEY, M.I. 1985. The ancient economy. 2nd edition. London: Chat to \& Windus.

GARNSEY, l'., K. HOPKINS \& C.R. WhitTAKER (ed.). 1983. Trade in the ancient economy. London: Chatto \& Windus

GlL.L, D.W.J. 1987. METRU.MENECE: an Etruscan painted inscription on a mid-5th-century Bc: red-figure cup from Populonia, Antiquity 61: 82-7.

1988. The distribution of Greek vases and long distance trade, in Christiansen \& Melander (ed.): 175-85.

1991. Pots and trade: spacefillers or objets d art?, Journal of Hellenic Studies 111:29-47.

1994. Positivism, pots and long-distance trade, in Morris (ed.): 99-107.

HANNESTAD, L. 1989. Athenian pottery in Etruria c. 550-470 BC, Acta Archaeologica 59: 113-30.

HuMPIIREYS, S.C. 1978. Anthropology and the Greeks. London: Routledge.

JOIINSTON, A.W. 1979. Trademarks on Greek vases. Warminster: Aris \& Philips.

MARKOE, G. 1992. In pursuit of metals: Phoenicians and Groeks in Italy, in G. Kopcke \& I. Tokumaru (ed.), Greece between east and west: 10th-8th centuries BC. Mainz: Zabern.

MELE, A. 1979. Il commercio greco arcaico: prexis ed emporie. Naples: Cahiers du Centro Jean Bérard 4.

MoRk1s, I. 1987. Burial and ancient society: the rise of the Greek city-state. Cambridge: Cambridge University Jress.

(Ed.). 1994. Classical Greece: ancient histories and modern archacologies. Cambridge: Cambridge Iniversity Press.

PARKER, A.J. 1992. Ancient shipwrecks of the Mediterranean and the Roman provinces. Oxford: British Archacological Reports. Internitional series 580 . 
I'OPIIAM, M. 1994. Precolonization: early Grevk contact with the East, in 'l'setskhladze \& De Angelis: 11-34.

PIIRCELL.L, N. 1990. Mobility and the polis, in O. Murray \& S.R.F. $\mathrm{l}^{2}$ rice (ed.), The Greek city from Homer to Alexander: 29 58. Oxford: Oxford University !'ross.

Rasmusslin, T. 1985. Ftruscan shapes in Attic pottery, Antike Kunst: $33-9$

RIDGWAy, D. 1992. The first Western Greeks. Cambridge: Cambridge University Press.

Robinson, E.G.D. 1990. Betwoen Greek and nativo: the Xonon Group, in J.-P. Descoeud res (ed.), Greck colonists and native populations: 251-65. Oxford: Oxtord Iniversity Pross.

ROSAT, R., L. QLARTILI \& M.P. GIERMANI)I. 1989. La ceramico attica nell Mediterraneo: analisi compaterizzata delle diffusione Le fasi initiali $630-560$ a. C. Bologna: Cooperativa Libraria Univorsitaria Editrice Bologna.

STI CROIX, G.E.M. Di. 1981. The class struggle in the ancient Greek world. London: Duekworth.

SCHEFlER, C. 1988. Workshop and trado patterns in Athenian black figure, in Christiansen \& Melander (ed.): 536-46.

SHIFTON, B.13. 1982. Greoks and Greek imports in the south of the Iherian poninsula, in H.G. Niemeyer (ad.), Phonizier im Westen: 337-70. Mainz: 'Zabern.

SNongRass, A.M. 1983. Hoavy treight in Archaic Groece. in Carnsey et al. (ed.): 16-26.

STuccln, S. 1984a. I vasi greci arcaici e la Cirenaica: importazioni ed influenze, Rendiconti dell' Accademia dei Lincei 39 : 161-71.

1984b. Die archäischen griechischen Vasen und dic Kyrenaika: Importe, Imitationen und Einflissse, in H.A.G. Brijder (ed.), Ancient Greek and related pottery: 139-43. Amsterdam: Allard Pierson.

TSETSKH].AD7., G.R. \& F. DE ANGTLIS (ed.). 1994. The archaeology of Greek colonisation. Oxford: Oxbow.

WrBster. T.B.I. 1972. Potter and patron in classical Athens. London: Methuen.

Whst. M.L. 1978. Hesiod Works and Days. Oxford: Oxford University Press.

WIld.IAMS, D.J. 1986. Greek potters and thoir descondants in Campania and southern Etruria, c. 720-630 BC, in J. Swaddling (ed.), Italian Iron Age artefacts in the British Museum: 295-304. I,ondon: British Museum Publications.

WiLliams, D.J. 1988. The late archaic class of eyo cups, in Christiansen \& Melander (ed.): 674-83 